\title{
TERRITORIAL EXPLORATION TO IMPLEMENT THE RECOMMENDATION ON HISTORIC URBAN LANDSCAPES FOR THE DEVELOPMENT AREA OF EL EJIDO IN CUENCA, ECUADOR
}

\author{
S. Auquilla ${ }^{1}$, M. Siguencia ${ }^{1, *}$ \\ ${ }^{1}$ University of Cuenca, Ecuador, Ciudad Patrimonio Mundial (CPM) Project, \\ ciudadpatrimoniomundial.com - (silvia.auquilla, maria.siguenciaa)@ucuenca.edu.ec
}

Commission II - WG II/8

KEYWORDS: Historic Urban Landscape, Landscape safeguard, Modern heritage, Buffer areas, El Ejido Cuenca.

\begin{abstract}
:
Cuenca in Ecuador is a growing city, weak in the face of the changes that the expansion phenomenon implies. The area of El Ejido was the first expansion area of the city with valuable samples of the arrival of modernity in the city. Nowadays, this sector is not exempted from the effects of urban growth and deserves to be managed through a proper management plan for its preservation. Degraded landscapes have been identified, modern heritage architecture shows clear symptoms of abandonment and low maintenance, causing the disappearance of historic buildings. Given these and other problems associated with urban development, Cuenca, like other cities, has taken the initiative of adopting the Recommendation on the Historic Urban Landscape (HUL) adopted by UNESCO in 2011, as a measure to safeguard urban heritage. In 2014, the implementation of this relatively new approach was first initiated in the pilot area of the Historic City Centre of Cuenca. This area was included in the World Heritage List in 1999 based on criteria II, IV, and V.However, aware of the significant heritage values embedded at El Ejido and its close urban and landscape link with the Historical City Center, the aim of this research is the implementation of the HUL's approach in a specific area located in El Ejido. Due to the clear difference between this sector and the Historical City Center, it is necessary to assess the first methodology used and work on a methodology that can be extrapolated to this sector and further on to other sectors of the city. To obtain the methodology for this area, it is essential to carry out a territorial exploration in cities with similar characteristics to Cuenca that are implementing an approach based on the study of the Historical Urban Landscape Recommendation.
\end{abstract}

\section{INTRODUCTION}

The 2011 Recommendation on HUL aims at urban heritage conservation and management at a macro level. At this level, the city values in both tangible and intangible dimensions are considered. The 2011 Recommendation laid out a holistic approach and has established a series of tools for the creation of new policies and practices for the safeguarding of cultural heritage and their contexts. This new approach goes beyond the concept of a Historic Centre and provides a broader perspective of a city, including not only isolated monuments but also the quality of its environment.

Cuenca began the implementation of the 2011 Recommendation with a multidisciplinary study that creates a proven methodology for the city's Historic Center. However, it has left pending the area of El Ejido, which has a direct link to the Historic Center and is part of its buffer and protection area. El Ejido has a modern heritage and urban characteristics worthy of preservation, however, thanks to the complications of urban growth and globalization it is being strongly threatened and deserves to be treated through a new management plan for its preservation.

El Ejido is the first area of expansion of the city where the first precedents of modernity were placed. In this area, the city abandons the checkerboard layout and proposes a concentric layout forming elongated blocks, following the concept of the Garden City. After this, El Ejido begins to live the implantation of important establishments and public equipment, like schools, hospitals, the University, orphanages, among others; this changed progressively and essentially the aspect of the sector.

Currently, degraded landscape areas have been identified, modern heritage architecture shows clear symptoms of abandonment and lack of maintenance, which causes the disappearance of valuable buildings, being replaced by high-rise buildings and architecture for commercial use, which have also determined the loss and elimination of green areas, the transformation of the Garden City, visual intrusion and concealment of important urban landmarks. Likewise, the lack of public policies, added to the implementation of ordinances that in a certain way promote "building renovation", among others, are factors that threaten the conservation of the sector.

These aspects have caused the transformation of the urban heritage, displacing the original uses, which was first a place of country houses, then was a residential area and now it is a branch of the Historical Center; putting at risk the citizen identity, the landscape and affecting the visuals from and to the area.

For these reasons, it is necessary to carry out a study that identifies the values to be protected in the area, using a methodological approach based on the territorial exploration of cities that are implementing the Historic Urban Landscape Recommendation.

\footnotetext{
* Corresponding author
} 
The three case studies that have put the HUL's approach into practice are La Plata (Argentina) and Puebla (Mexico) which belong to the World Heritage list and they have created institutions to work on a holistic approach to heritage care and the urban context, and Valparaiso (Chile) shows an inciting work of citizen participation. In every implementation, a variety of tools are used. These tools, embedded in the 2011 Recommendation on HUL, suggest an adaptation depending on the different local contexts and realities.

The 2011 Recommendation suggests taking into account the local context of each historic city. This results in different approaches to the management of each one, taking as a guide the 6 steps for the implementation of the 2011 Recommendation. From these cases, good practices were obtained that may apply to the area of El Ejido, which leads to the establishment of a methodology adapted to be implemented.

\section{TERRITORIAL APPROACH OF THE HUL}

In general, laws, policies, and initiatives for urban conservation are managed through the definition of protection zones. In these areas, monumental buildings and traditional urban fabric stand out. Most of the time, their management is carried out with autonomy from the rest of the city. However, little work has been done outside these protection zones to preserve urban heritage. It is yet necessary to raise actions for controlling and mitigating negative impacts on the outskirts of the city. The impacts include the detrimental visual impact due to new urban and architectural developments, the denial of the physical and functional relationship between the historical and non-historical areas, amongst others (Conti, 2018).

A significant aspect of the HUL's approach is the broadening of the territorial focus, going beyond the traditional notion of historical areas or centers to include, and protect, larger environments, both built and natural. In this way, the notion of HUL synthesizes the advances of recent years with a broad and comprehensive conception of heritage, including natural and cultural, tangible, and intangible components. In this way, cities are considered as the result of a process that has taken place over time, and that will continue, rather than as a static object (Conti, 2018).

Besides, the HUL's approach seeks to integrate the objectives of heritage conservation with the objectives of Sustainable Development Goals (SDG) promoted by the United Nations (UN), to work on the response to current requirements and needs in terms of urban management, and finally to promote participatory management as a means of balancing the current and future needs of society. This approach considers urban heritage as a social, cultural, and economic asset in the development of cities (Pesci, 2017).

Achieving the SDGs requires the commitment and active participation of three orders of government: public administration, responsible for establishing the basic and common structures; the private sector, playing a decisive role in the implementation of Agenda 2030; and civil society. The joint effort of actors will bring about change to bequeath a prosperous future to the next generations (UN, 2016).

In summary, the 2011 Recommendation responds to the need to better integrate and articulate urban heritage conservation strategies with broader global sustainable development objectives to support public and private measures to preserve and improve the quality of the human environment. It proposes a landscape approach for the selection, conservation, and management of historic areas in their overall urban context.
The draft proposal of the 2011 Recommendation provides a six-step action plan and tools to ensure that culture, in all its forms, becomes and remains as a facilitator and driver of sustainable development.

\subsection{The implementation of HUL}

The tools proposed by the Recommendation on HUL imply not only a conceptual change from traditional approaches but also a paradigm shift in terms of planning, management processes, methods, and instruments. The HUL's approach looks at specific features in the cities' contexts and therefore different management approaches for each city. The six-step action plan, as well as a series of management tools, indicate the basic steps that would facilitate the implementation of the HUL approach and that can be adaptable to each environment.

The Historic Urban Landscape approach conditions to know the local context of each historic city. This leads to a different management approach for each city, so the document indicates at least six basic steps to facilitate the implementation of the HUL's approach and a series of tools adaptable to each environment.

2.1.1 Six-step action plan: This action plan consists of the following activities:

1. To carry out exhaustive studies and maps of the natural, cultural and human resources of the city;

2. To reach a consensus through participatory planning and stakeholder consultations on which values to protect to pass them on to future generations and to identify the attributes that carry these values;

3. To assess the vulnerability of these attributes to socioeconomic stress and the impacts of climate change;

4. Integrate urban heritage values and their state of vulnerability into a broader city development framework, which will provide indications of areas of sensitivity that require careful attention in the planning, design, and implementation of development projects;

\section{Prioritize conservation and development actions; and}

6. Establish appropriate partnerships and local management frameworks for each of the identified conservation and development projects, as well as develop mechanisms for the coordination of the various activities among different actors, both public and private (UNESCO, 2011).

2.1.2 Management tools: Successful management for the conservation of urban heritage requires a set of solid tools (Figure 1) that are constantly being studied. Interdisciplinary and innovative tools can be organized into four different categories. It should be emphasized that for successful urban heritage management, policies, and actions in these four categories must be adapted to local contexts and addressed simultaneously, as they are interdependent (UNESCO, 2016).

\footnotetext{
- Knowledge and planning tools

- Citizen participation tools

- Regulatory systems

- Financial tools
} 


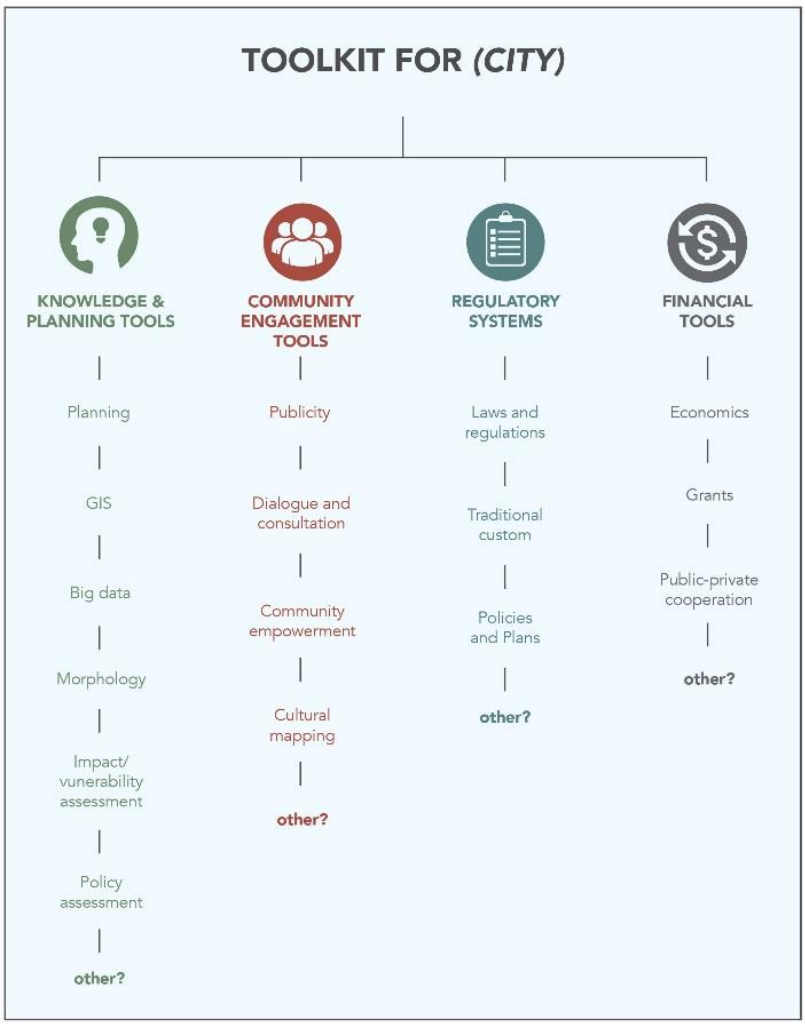

Figure 1. Toolkit for the city, Source: The HUL Guidebook.

\section{IMPLEMENTATION OF HUL IN CUENCA}

Following the 2011 Recommendation on HUL, several cities have joined the list of cities interested in conducting studies on the subject, to apply the tools integrated within the 2011 Recommendation. Before developing the methodology implemented for Cuenca, in the first stage of the study, four experiences were analyzed: Seville, Ballarat, Zanzibar, and Edinburgh. This methodology, which began in 2014, focused its work on the city's historic city center, leaving the first area of the city's expansion -El Ejido- pending. In this area, the first precedents of architectural modernity are to be found in Cuenca.

Considering the significance of El Ejido and its close connection with the Historic Center of the City, the aim is to implement the HUL approach and to build on the existing methodology, developed for the first study (for the Historical Center only). For this purpose, it is necessary to take as a reference the methodologies applied in different cities, which can contribute in the case of Cuenca, and strengthen the methodology already mentioned. It was necessary to analyze current projects in case studies that use tools suggested in the Recommendation on HUL. These case studies are considered as cases where information and guidelines can be obtained and might have not been taken into account for the case of Cuenca yet.

\subsection{Implementation in the Historical City Center.}

The implementation of the HUL's approach in Cuenca began with a theoretical-conceptual framework, which continued with the delimitation of landscape units, starting the first sweep of information layers that allowed to group certain zones with homogeneous characteristics (Siguencia, Rey, 2016).
Starting with this delimitation, a second stage allowed the adoption of a methodology where information gathering and overlaying of data took place in most of the areas, first focused in the Historical City Center, due to the availability of information and the ease of obtaining data from various sources.

With this information, heritage values and vulnerabilities were identified through participatory workshops with the community (steps 2 and 3 of the six-step action plan). Also, the resulting units were validated, defining the second phase as, landscape units evaluation.

Finally, in a third phase, landscape assessment sheets were produced. Here, all the information gathered was put into a model sheet for monitoring the different units. The model sheet was not conceived as an end, but as a means to identify cultural values and as a tool to promote heritage management (Siguencia, Rey, 2016).

\begin{tabular}{|l|l|}
\hline & Heologic and hydrologic \\
\hline
\end{tabular}

Figure 2. Methodology base, Source: authors.

\subsection{Implementation in El Ejido}

3.2.1 Characteristics of El Ejido: The area of El Ejido is the first urban sprawl of the city of Cuenca carried during modern times in the mid-twentieth century. El Ejido is a former space for agriculture and grazing that became a modern residential area inspired by the Garden City. It is located across the historical center (Figure 3) from which it is naturally separated by the "Tomebamba" River and "The Bluff". From the early days of the colony, El Ejido supplied the city with farm products and consisted of a peri-urban area, limited to the residence of indigenous and mestizo strata.

El Ejido is known as the first area of expansion of the founding city of Cuenca, an expansion undertaken during the modern architectural movement. The area of El Ejido went from being a brownfield to become the modern residential area inspired by the 
Garden City. It is divided from the historical city center by an important water axis and "El Barranco", a group of buildings located in the change of slope. Therefore, El Ejido is naturally separated from the Historic City Center (Figure 4). Since the early colonial times, it supplied the city with agricultural products. In this sense, this zone was born as a periurban area, limited to the residence of indigenous and mestizo strata.

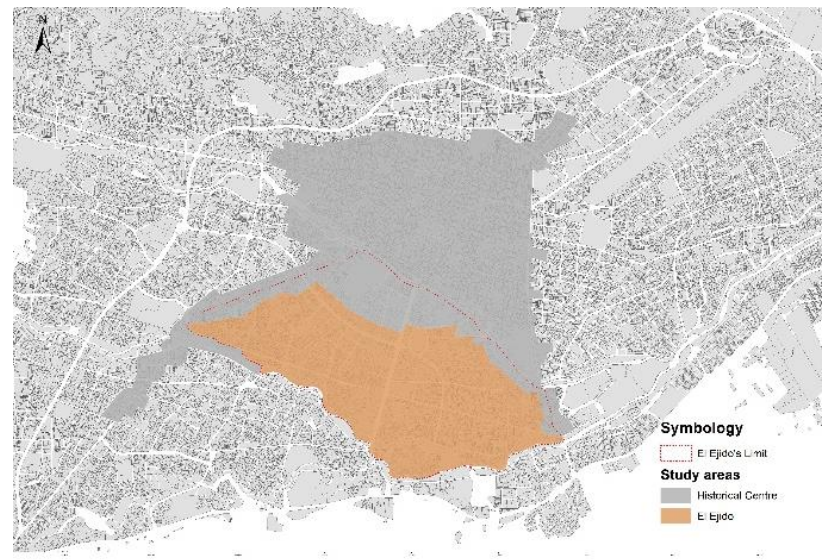

Figure 3. Location of El Ejido and its spatial relation with the Historical City Center. Source: authors.

By the XIX century, Cuenca had accelerated economic and population growth. The economic boom deeply changed the architecture of the Historical City Center, since money was invested in remodeling representative and civil buildings. At the same time, wealthy families migrated to El Ejido giving way to radical transformations, including the first Master Plan with the inclusion of leisure areas for private enjoyment, the so-called villa houses, and recreational zones for public use.

Thus, the design of the Master Plan adopts the concepts of the Garden City, with houses of isolated implantation, and streets with wide sidewalks with green areas. The area of El Ejido is geographically defined in an east-west direction, considering the two historical entries and exit routes of the city, while in a northsouth direction, the limits constitute important natural axes for the city; two rivers and two historical streets, part of the area defined as World Heritage Site. These conditions constitute an added value of singular environmental and landscape richness that must be protected together with the valuable samples of modern architecture. El Ejido also maintains public-green spaces distributed throughout the area and a unique boulevard in the city.

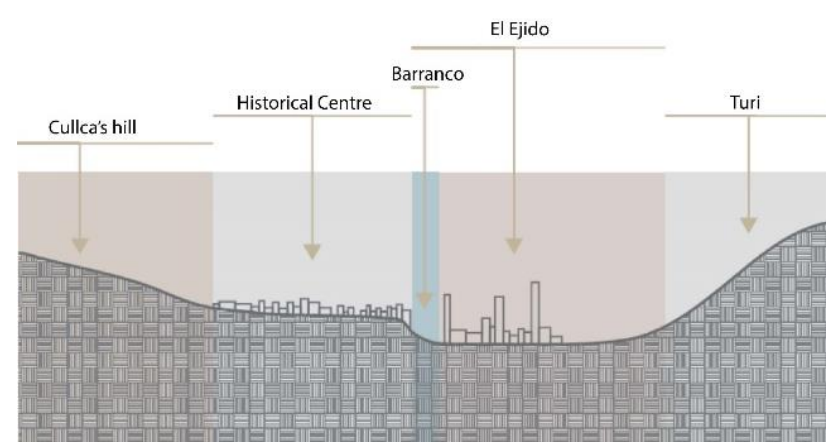

Figure 4. Topography of the city of Cuenca. Source: Criollo, Herás, Macancela, Washima, 2007.

\subsubsection{Value assessment}

To identify the perception of the citizens in the study area, a workshop was held within the framework of the event "The Cuenca landscape, a look under construction". The aim was identifying significant elements, based on the perception of technicians and citizens, as well as detecting landscape elements that contribute to the understanding and configuration of $\mathrm{El}$ Ejido, in addition to those elements that are aggressive in the landscape context.

The results obtained were grouped into six categories that reflect the opinion of the participants. The vast majority of participants agreed on the recognition of representative elements of El Ejido (Cardoso, 2016). The categories are grouped in different general topics as follows:
1. Nature
2. Urban patterns of settlement
3. Axles, tracks
4. Visuals
5. Architecture/Tangible
6. History, Use/Intangible

The presence and relationship with nature remain as the most representative and frequent characteristic in El Ejido. For this reason, it also reflects the importance that the community gives to the striking mountainous skyline seen from an observation point in the city. Road axes define the urban structure of the sector and that, in a certain way, act as limits of a structure similar to the "Garden City".

It is possible to observe architecture recognized with heritage values in the zone, like one of the first samples of "Modern Architecture" in the city. Besides, it is valued the way of implantation of the villas and/or "quinta" that at that time were shown as the most representative image of El Ejido; nowadays, several have been replaced by new architectural examples sometimes qualified as negative.

When people were asked to improve the current state of the area by clearing out features and buildings, the results were higher and scattered. In other words, the number of features that people assign value to is less than those considered as a hazard. These hazards were mainly buildings found as aggressive to the landscape. This fact leads to the question of the quality of architecture in EL Ejido and the alteration of its landscape due to increasing real estate interests. Many factors hit upon change of the environment; however, the quality of the architectural design, inserted in the last years, remains as the biggest problem (Cardoso, 2016).

Given this background, it could be said that the problems of El Ejido to be solved can be summarized in the following points:

1. Loss of local vegetation and fauna.

2. Buildings at height.

3. Visual pollution.

4. Loss of cultural diversity and authenticity.

5. De-actualization of public policies.

6. Land-use changes and gentrification.

7. Vehicle traffic.

8. Loss of built heritage. 


\subsubsection{Methodological contribution for El Ejido}

Along with the information obtained during the participatory workshops, the number of cases studied revealed the existence of different guidelines for urban conservation in the light of implementing the Recommendation on HUL. These case studies were selected based on their similarities to El Ejido so that the approach used could potentially be adaptable. Some of the guidelines in these case studies include:

1. Identification and definition of landscape types, where it is proposed as part of the study of the microscale, landscapes as connecting systems (a network of public spaces).

2. Definition of scenarios to regulate the city's development.

3. Identification of relevant visuals.

4. A platform for the diffusion of heritage:

- Dissemination of neighborhood groups and heritage identified by the community.

- Dissemination platforms to value El Ejido and raise awareness among citizens.

- Communication plan and citizen participation (community actors - public-private).

- Placement of commemorations signs to provide information on buildings.

- System for generating alerts so that the community can make suggestions, complaints, or questions about heritage conservation.

5. Emerging Management Plan implemented until the regulatory framework is analyzed and the respective reforms are made for the elaboration of a proper Territorial Sustainability Plan for the Historic Urban Landscape.

- Tax incentives.

- A technical standard of Design and urban image.

6. Territorial Sustainability Plan for the Historic Urban Landscape, action Plan:

- Multiple instruments and public-private programs.

- Integrated transport system.

- Sightseeing tours.

- Inventory of green areas.

- Implementation of native vegetation (green corridors).

- Road maintenance.

- Recovery of the urban concept.

The methodological proposal aims to include the community point of view as well as the successful experiences in the case studies analyzed. This proposal is carried out using a comparative table between the previous methodology used for the Historical City Centre of Cuenca and the contributions above listed from the case studies analyzed.

The previous methodology suggests 3 phases of study, Diagnosis, Definition of landscape units, and Landscape assessment sheets, phases that correspond to the six-step action plan from the draft proposal of the Recommendation on HUL. For this reason, the comparative analysis with the contributions of the case studies is proposed, in such a way that guidelines embedded in surveys and implemented projects - are added to the corresponding phases already established and better allow the vision of what is still needed for the methodology to be implemented in El Ejido.
Finally, the following characteristics are added to the methodology: definition of scenarios, emerging plans, and execution of public-private programs and projects. These characteristics that were not addressed in the previous methodology for the Historical City Center are now part of the studies proposed in the methodology for El Ejido. They are part of the fourth phase so-called action plan.

The process of creating the methodology, the comparison with the previous methodology, the contribution of the case studies, and how these could solve the problems of the sector are shown in table 1 (Annex).

The changes or adjustments that have been implemented in each phase are as follows:

Phase 1: "Diagnosis and state-of-the-art". In this phase, new information (layers) and studies that were not taken into account in the first methodology (for the Historical City Center only) are incorporated. They include the identification and analysis of landscape types, relevant images, socio-economic status of inhabitants, and archaeological sites.

Phase 2: "Definition of Study Area". Based on the first methodology (for the Historical City Center only) landscape units or areas are defined in phase 2. It consists of the grouping of areas by homogeneous characteristics to facilitate analysis and management. Therefore, the proposed method adopts the definition of landscape units or areas and proposes a validation process of these boundaries (process explained in section 4). Units or subunits of similar characteristics allow more effective implementation of actions. Also, within each unit, different types of the landscape can be identified.

Phase 3: In the third phase, landscape assessment sheets are drawn up, in which the current state of each landscape unit is explained, as well as the values and problems to be solved. In the new methodology, in addition to highlighting the current state of each unit, it is proposed to create a platform for the dissemination of heritage, so that people know the values that exist in the city, not only those recognized on the world heritage list but also those that the community identifies as valuable. The objective is to get people involved in heritage conservation and to create positive or negative alerts about how heritage management is carried out in the city.

Phase 4: The action plan takes into account emerging plans that will slow down the effects on the landscape until strategies and programs for its conservation can be developed.

\section{INITIAL IMPLEMENTATION IN EL EJIDO}

To implement the proposed methodology in the area of El Ejido, it is important to consider the intrinsic territorial differences. According to the units 8,10, and 11 (Figure 5) previously defined in El Ejido (as part of the first methodology for the Historical City Center only) (Siguencia, Rey, 2016), the one that meets the widest range of features was selected for the pilot implementation. This selection criteria guarantees that it can be replicated in further areas of El Ejido in the future.

The unit chose (10, Figure 5), focuses on representing the first expansion zone of the city and one of the direct limits with the Historical City Center. This unit (10, Figure 5) has also important signs of the arrival of architectural modernity in the city, not only in terms of buildings but also in spatial distribution. 


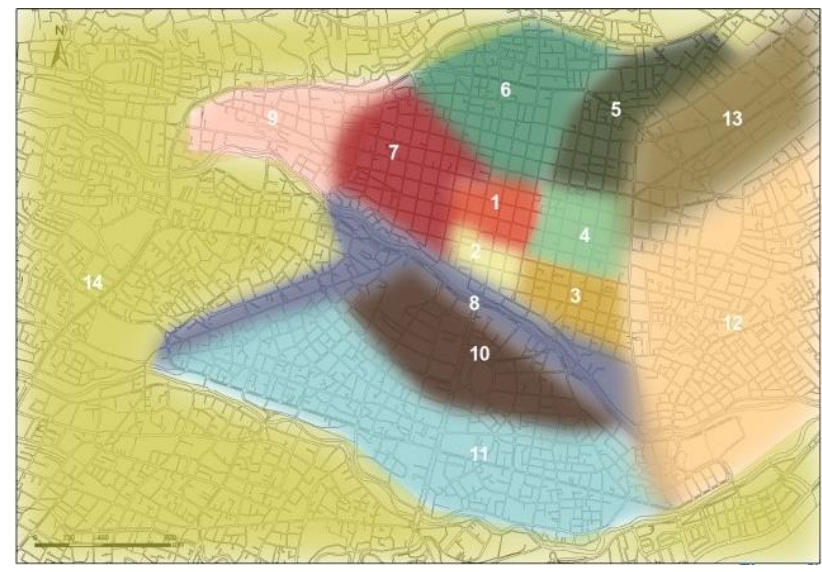

Figure 5. Landscape units 8, 10, 11 that make up the area of El Ejido. Source: Siguencia, 2014.

The implementation of the methodology implies an initial joint work between phases 1 and 2 . The definition of the study area depends on the collection of information from some study layers that are proposed to be identified in phase 1. But in phase 2 the contribution to the methodology implies the validation of the delimitation and the identification of landscape sub-units.

First, a sub-unit of study is defined, using the same methodology of overlapping of layers, to subdivide unit 10 (Figure 6) into groups of similar characteristics as a useful tool for its management and analysis. Also, to delimit these homogeneous areas, the methodology of the delimitation of landscapes of cultural interest (PICA) in Andalusia - Spain, is also used. Here, areas are characterized and identified, both by the characteristics that differentiate them and those that relate them. They are classified and characterized taking into account criteria such as space, evolution, dominant structural elements, etc. Adopted for this study is the classification of areas by their spatial characteristics. According to this, landscapes are classified in:

1.Punctual

- By location (points of view)

- By spatial reference/symbolism (places of reference in the territory)

2.Linear

- By continuity (continuous linear axes)

- By interrelationship (discontinuous linear axes)

3.Of networks

- For continuity (continuous mesh)

- By interrelationship (discontinuous mesh)

4. Area

- By delimitation (limited area)

- By diffusion (not limited area)

Using these two methodologies, the axes (natural axes such as the river and road hierarchy), points of interest (landmarks and nodes) and existing areas in the unit (a division of areas into parishes and neighborhoods), plus the layers of information, are identified to begin the division of unit 10 .

The subdivision considered the partition of the city into parishes, plus the application of the road hierarchy. These two aspects can already divide the unit into two parts. In half of unit 10, important equipment, public spaces, heritage buildings, affections, and infractions to the regulations of several types are recognized by the citizens.

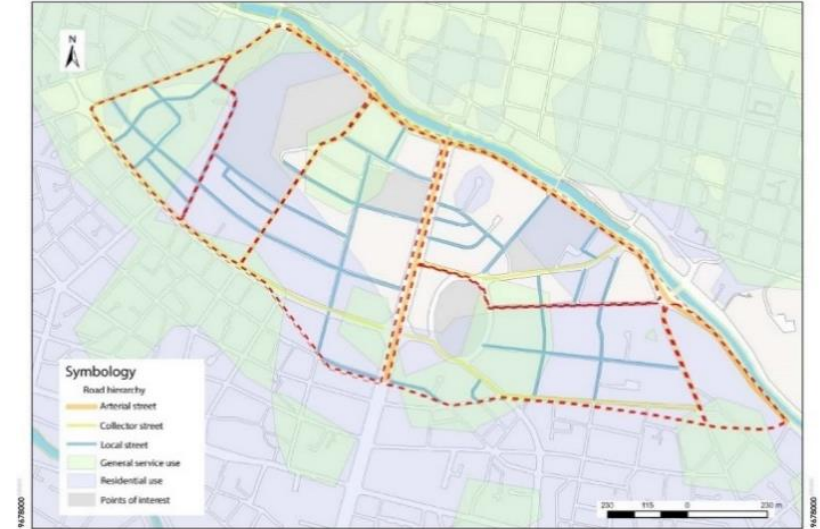

Figure 6. Third division of the unit according to the uses of general and residential services. Source: authors.

The analysis continues with the crossing of layers of land use, heritage assessment of buildings and road hierarchy, where areas of communal use (nurseries, kindergartens, schools, etc.) and management and administration use prevail. These can be clearly defined and grouped as sub-units.

The overlap of the concentration layer of residential use and general services reinforces the overlap of the previous layers and also helps to differentiate the areas. It can be seen that in El Ejido, residential use is gradually being lost due to the increase of buildings with general services and management, and in some cases, these uses coexist together.

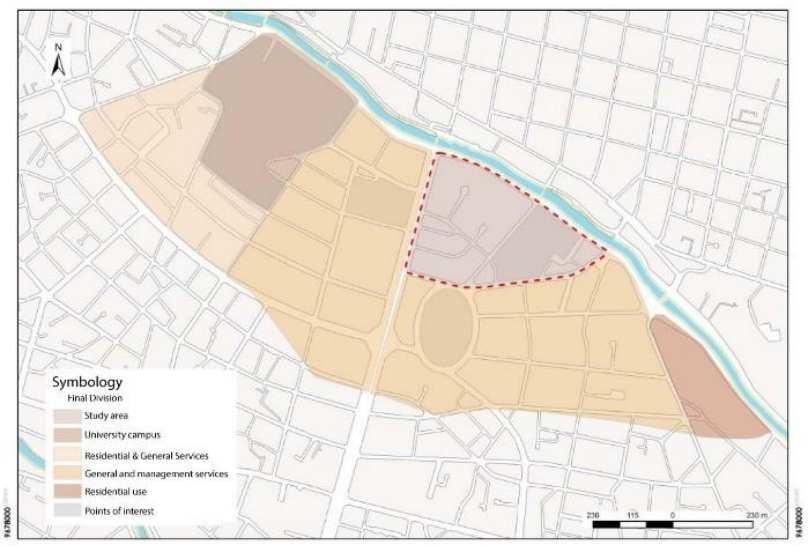

Figure 7. Delimitation of the study area. Source: authors.

The delimited zone shown in figure 7 contains elements that make it potential for a landscape study area, such as its immediate context and the elements found in it. In this area, there are Universities, use of general services such as Banks, Chamber of Commerce and Industries, buildings linked to health and important public spaces for the city. The presence of heritage buildings cataloged as being of high value as well as the persistence of residential use in the area are also noteworthy. All these elements mentioned plus the aggressions to this area and the immediate context that have occurred, make the place an element to apply the landscape study.

To complete phase 2 , a validation of the delimitation is necessary, thus initiating the transition to phase 3 , through the involvement of the community. A survey is carried out with residents of the sector, users and people from outside the area to obtain data to assess the landscape in the area and to corroborate the selected limits, allowing the final definition of the sub-unit. 
After the analysis of the area of study and its immediate surroundings, it has been possible to determine the values that characterize it, which must be preserved and enhanced so that the identity of the sector is not lost. Similarly, after visits and dialogs with stakeholders linked to the area, it is evidenced that some of the problems directly attempt to their significant values.

In this way, the characterization of the landscape, proposed in phase 3 , is fulfilled. Information is disseminated to conclude the assessment process and people can learn about the heritage of the area and its problems. This knowledge can help to conserve and alert citizens about the conditions of heritage. The identification of the values and vulnerabilities of the sector allows activating the action plan phase. According to the state of the area, it is necessary to first propose an emerging plan while a definitive management plan for the area is developed.

\section{CONCLUSIONS}

The application of the 2011 Recommendation in the area of El Ejido as a management tool results in the adjustment of a previous methodology developed for the Historical City Center. This methodology responds to the good practices obtained from the case studies analyzed. Also, the comparison with what was previously elaborated in the case of Cuenca and considering the problems identified in the sector.

The analyses of the case studies allow the understanding of how to face the conservation of the HUL differently since each case is approached according to its context. However, it has been concluded that the case of Cuenca is one of the most complete ones in terms of implementation, as it follows the six-step Action Plan set out in the draft proposal of the Recommendation on HUL.

The difference between Cuenca and the rest of the case studies is that several of them already propose programs, projects, activities, and recommendations for the conservation of urban heritage. These are models to be properly analyzed and adapted to the context of El Ejido, in addition to other aspects that feed or complement the previous phases.

It is important to mention that the interest to adjust the methodology is due to the notable differences between the historical city center and the area of El Ejido. Nevertheless, it can be said that, although they are different sectors, the methodology in most of their studies applies to both areas. It was thought that the case studies, especially the case of La Plata in Argentina, would be of great contribution to El Ejido because they both consist of modern examples of heritage. The contributions of this case study do not specify a clear approach for this type of heritage study. They are rather general studies that can be transferred to any scenario.

Therefore, it could be said that the application of the 2011 Recommendation in the area of El Ejido does not create a specific methodology for this sector. It is rather a methodological contribution that complements the previous study and establishes a differentiated methodology, complemented by more studies. Concluding in an action plan that allows for recommendations, intervention guidelines, and improvement projects. Finally, the methodology obtained is as follows:

- Diagnosis and state-of-the-art

- Identification of landscape units or area of study

- Landscape assessment sheets

- Action plan.
Finally, the methodological adjustment allows us to understand that it is not necessary to create different methodologies for each zone. Instead, a complete methodology is needed to allows us to know the current status of different areas. It also allows for a clear process of studies and decision making, which guarantees its applicability in different places based on their specific context.

\section{REFERENCES}

Cardoso, F., 2016. Discursos y experiencias para la gestión del patrimonio. Cuenca.

Conti, A., 2018. La Conservación y la Gestión de las Ciudades Históricas desde la Perspectiva del Paisaje Urbano Histórico, 113. Retrieved from http://sedici.unlp.edu.ar/bitstream/handle/ 10915/50335/Documento_completo.pdf-PDFA.pdf?sequence=3

ONU, 2016. Agenda 2030 y los Objetivos de Desarrollo Sostenible Una oportunidad para América Latina y el Caribe. Retrieved from www.un.org/sustainabledevelopment/es

Pesci, R., 2017. Buenas Prácticas de Paisaje - Curso Proyectar el Paisaje.

Siguencia, M., Rey, J., 2016. Heritage Values Protection, from the monument to the urban dimension. Case study: The Historic Centre of Santa Ana de los Ríos de Cuenca. The Historic Environment: Policy and Practice [En Línea]., 7 (2).

UNESCO, 2011. Recomendación sobre el paisaje urbano histórico, con inclusión de un glosario de definiciones. Retrieved September 11, 2018, from http://portal.unesco.org/es/ev.phpURL_ID=48857\&URL_DO=DO_TOPIC\&URL_SECTION=20 1.html

UNESCO, 2016. The HUL Guidebook. In The HUL guide (p. 59). Retrieved from ttp://historicurbanlandscape.com/themes/ 196/userfiles/download/2016/6/7/wirey5prpznidqx.pdf 
The International Archives of the Photogrammetry, Remote Sensing and Spatial Information Sciences, Volume XLIV-M-1-2020, 2020

HERITAGE2020 (3DPast | RISK-Terra) International Conference, 9-12 September 2020, Valencia, Spain

\section{APPENDIX}

\begin{tabular}{|c|c|c|c|c|c|c|c|c|c|}
\hline \multicolumn{4}{|c|}{ Previous methodology } & \multicolumn{4}{|c|}{ Case Study Analysis and problems of El Ejido } & \multirow{2}{*}{\multicolumn{2}{|c|}{$\begin{array}{l}\text { Methodological contribution } \\
\text { for El Ejido }\end{array}$}} \\
\hline \multirow[t]{2}{*}{ Phases } & \multicolumn{2}{|c|}{ Historic Centre } & \multirow{2}{*}{$\begin{array}{l}\text { El Ejido } \\
\text { Analysis }\end{array}$} & \multirow[t]{2}{*}{ Case studies } & \multicolumn{2}{|c|}{$\begin{array}{l}\text { Allows } \\
\text { solution }\end{array}$} & \multirow[t]{2}{*}{ Problematic } & & \\
\hline & Components & Analysis & & & Yes & No & & & alysis \\
\hline \multirow{17}{*}{$\begin{array}{l}\text { 1. Diagnosis } \\
\text { and state-of- } \\
\text { the-art }\end{array}$} & \multirow{10}{*}{ Territorial } & Geology & Geology & & & & & \multicolumn{2}{|l|}{ Geology } \\
\hline & & Biology & Biology & & & & & \multicolumn{2}{|l|}{ Biology } \\
\hline & & Regulations & Regulations & & & & & \multicolumn{2}{|l|}{ Regulations } \\
\hline & & Cartography & Cartography & & & & & \multicolumn{2}{|l|}{ Cartography } \\
\hline & & Land uses & Land uses & & & & & \multicolumn{2}{|l|}{ Land uses } \\
\hline & & Density & Density & & & & & \multicolumn{2}{|l|}{ Density } \\
\hline & & Socio-economic & & & & & & \multirow{2}{*}{\multicolumn{2}{|c|}{\begin{tabular}{|l} 
Socio-economic \\
Public spaces
\end{tabular}}} \\
\hline & & Public spaces & Public spaces & & & & & & \\
\hline & & & & $\begin{array}{l}\text { 1. Definition of } \\
\text { landscape types }\end{array}$ & $\mathrm{x}$ & & $\begin{array}{l}\text { Loss of local } \\
\text { vegetation and } \\
\text { fauna }\end{array}$ & \multicolumn{2}{|c|}{\begin{tabular}{||l} 
Public spaces \\
Definition of landscape types
\end{tabular}} \\
\hline & & & & $\begin{array}{l}\text { 3. Identification of } \\
\text { relevant visuals }\end{array}$ & $\mathrm{x}$ & & $\begin{array}{l}\text { High-rise buildings } \\
\text { / Visual pollution }\end{array}$ & \multicolumn{2}{|c|}{ Identification of relevant visuals } \\
\hline & \multirow{5}{*}{ Heritage } & Archaeology & & & & & & \multicolumn{2}{|l|}{ Archaeology } \\
\hline & & Anthropology & Anthropology & & & & & \multicolumn{2}{|l|}{ Anthropology } \\
\hline & & Architectural Typologies & Architectural Typologies & & & & & \multicolumn{2}{|c|}{ Architectural Typologies } \\
\hline & & Property Valuation & Property Valuation & & & & & Property Valu & \\
\hline & & State of conservation & State of conservation & & & & & State of conse & vation \\
\hline & \multirow{2}{*}{ Perceptive } & Historical Photography & Historical Photography & & & & & \multicolumn{2}{|c|}{ Historical Photography } \\
\hline & & Citizen's vision & Citizen's vision & & & & & \multicolumn{2}{|l|}{ Citizen's vision } \\
\hline \multicolumn{2}{|c|}{$\begin{array}{l}\text { 2. Identification of } \\
\text { landscape units }\end{array}$} & 7 units & 3 units & $\begin{array}{l}\text { 2. Definition of } \\
\text { scenarios }\end{array}$ & & & & \multicolumn{2}{|c|}{ 2. Definition of study area } \\
\hline \multirow{2}{*}{\multicolumn{2}{|c|}{$\begin{array}{l}\text { 3. Landscape assessment } \\
\text { sheets }\end{array}$}} & \multirow{2}{*}{7 worksheet } & & 4. Platform for the & & & Loss of cultural & \begin{tabular}{|l} 
Landscape $\mathrm{Ch}$ \\
Valuation diffu
\end{tabular} & $\begin{array}{l}\text { racterization } \\
\text { on platforms }\end{array}$ \\
\hline & & & 3 worksheet & $\begin{array}{l}\text { dissemination of } \\
\text { heritage }\end{array}$ & x & & $\begin{array}{l}\text { diversity and } \\
\text { authenticity }\end{array}$ & $\begin{array}{l}\text { Communicatio } \\
\text { participation }(A\end{array}$ & $\begin{array}{l}\text { plan and citizen } \\
\text { ert system) }\end{array}$ \\
\hline & & & & $\begin{array}{l}\text { 5. Emerging } \\
\text { management plan }\end{array}$ & $\mathrm{x}$ & & $\begin{array}{l}\text { De-actualization } \\
\text { of public policies }\end{array}$ & & \\
\hline & & & & $\begin{array}{l}\text { conjunction with the } \\
\text { management plan }\end{array}$ & $\mathrm{x}$ & & \begin{tabular}{|l|} 
Land use changes \\
and gentrification
\end{tabular} & 4. Action & $\begin{array}{l}\text { management } \\
\text { plan }\end{array}$ \\
\hline & & & & & $x$ & & Vehicle traffic & & Multiple \\
\hline & & & & 6. Action plan & $\mathrm{x}$ & & $\begin{array}{l}\text { Loss of built } \\
\text { heritage }\end{array}$ & & $\begin{array}{l}\text { Instruments and } \\
\text { public-private } \\
\text { programs. }\end{array}$ \\
\hline
\end{tabular}

Table 1. Analysis of the comparison between the existing methodology, case studies, and the problems of the El Ejido, for the methodological contribution. 